University of Wollongong

Research Online

Faculty of Business - Papers (Archive)

Faculty of Business and Law

2016

Does the military turn men into criminals? New evidence from Australia's conscription lotteries

Peter Siminski

University of Wollongong, siminski@uow.edu.au

Simon Ville

University of Wollongong, sville@uow.edu.au

Alexander Paull

University of Wollongong, alp998@uowmail.edu.au

Follow this and additional works at: https://ro.uow.edu.au/buspapers

Part of the Business Commons

Research Online is the open access institutional repository for the University of Wollongong. For further information contact the UOW Library: research-pubs@uow.edu.au 


\title{
Does the military turn men into criminals? New evidence from Australia's conscription lotteries
}

\begin{abstract}
In this paper, we estimate the effect of military service on the perpetration of crime. Several hypothesized links exist between service and crime, but recent quasi-experimental studies on this subject have produced mixed results. Our contribution to this literature uses Australia's Vietnam era conscription lotteries for identification along with criminal court data from Australia's three largest states. We find no evidence that military service increases or decreases crime in any category. In our preferred specification, the $95 \%$ confidence interval rules out positive (negative) effects larger than $11 \%$ (10\%) relative to the mean crime rate.
\end{abstract}

\section{Keywords}

military, turn, men, does, into, lotteries, criminals, evidence, australia, conscription

Disciplines

Business

\section{Publication Details}

Siminski, P., Ville, S. \& Paull, A. (2016). Does the military turn men into criminals? New evidence from Australia's conscription lotteries. Journal of Population Economics, 29 (1), 197-218. 


\title{
Does the Military Turn Men Into Criminals? New Evidence from Australia's Conscription Lotteries*
}

\author{
[forthcoming in the Journal of Population Economics]
}

\author{
Peter Siminski, Simon Ville and Alexander Paull \\ University of Wollongong
}

November, 2014

${ }^{*}$ We are grateful to two anonymous referees, Joshua Angrist, William N. Evans, Jason M. Lindo, Alfredo R. Paloyo, Joan R. Rodgers and seminar participants at the Melbourne Institute of Applied Economic and Social Research, the University of Technology Sydney, the University of Queensland, the University of Tasmania, and the University of Wollongong for discussions and comments. We thank Daniel Thomason for excellent research assistance. For criminal court data we are grateful to NSW BOCSAR, the Queensland Department of Justice and Attorney-General, and the Victorian Department of Justice. We acknowledge grant support from the Australian Research Council (LP100100417 and DE120101642) and the Department of Veterans' Affairs. The views expressed in this paper are the authors' alone, as are any errors of fact or omission. 


\begin{abstract}
In this paper, we estimate the effect of military service on the perpetration of crime. Several hypothesized links exist between service and crime, but recent quasi-experimental studies on this subject have produced mixed results. Our contribution to this literature uses Australia's Vietnam-era conscription lotteries for identification along with criminal court data from Australia's three largest states. We find no evidence that military service increases or decreases crime in any category. In our preferred specification, the $95 \%$ confidence interval rules out positive (negative) effects larger than $11 \%(10 \%)$ relative to the mean crime rate.
\end{abstract}

JEL Codes: H56; I12; J45 Keywords: Crime; Military Service; Australia

\title{
1. Introduction
}

The relationship between military service and crime has been studied from various angles and with various motivations. For example, economists have long been concerned about the link between conscription and foregone civilian labor market experience, which may reduce subsequent earnings (Angrist 1990; Oi 1967). Lower potential earnings from formal work would, in turn, increase comparative advantage in illegal work. Conversely, conscription often has been proposed as a strategy for 'getting youth off the streets' - to socialize them and build pro-social values. However, military experience also may directly enhance productivity in illegal work through the provision of weapons training and possibly through social capital networks. Effects on violent crime are also hypothesized to stem from the psychological effects of witnessing combat, the stress of potential combat, and from indoctrination into masculine military culture. 
Finally, military experience has the potential to affect soldiers' risk preferences, which also are linked to criminality.

To date, the empirical evidence on the relationship between military service and crime is mixed. Several recent studies, each adopting credible identification strategies, investigated the effects of military service on crime. Two studied non-deployed service, in Argentina (Galiani et al. 2011) and Denmark (Albæk et al. 2013) respectively, using conscription lottery IV identification. While neither found effects on violent crime, the results for property crime are opposing. Conscription was found to increase property crime in Argentina. The authors suggest that the reduced economic opportunities associated with conscription may explain this result. In contrast, military service was found to decrease property crime in Denmark, with socialization proposed as the mechanism behind this result.

A pair of American studies of Vietnam veterans suggests positive effects of military service on violent crime. Using conscription lottery identification, Lindo \& Stoecker (2014) found a positive effect of Vietnam-era service on violent crime but negative effects on non-violent crime. Exploiting between-cohort variation, Rohlfs (2010) found a positive effect of combat intensity on violence among US veterans of Vietnam. In another paper, Anderson and Rees (forthcoming) examined how local crime rates near the Fort Carlson military base changed in response to the composition of troops stationed there. They found that the number of previously deployed units was not a statistically significant short-run determinant of crime. ${ }^{2}$

Overall, the results of these previous studies are mixed, suggesting that the effects of service are heterogeneous. The differences in results among countries may reflect corresponding differences in the nature of the military experience, or in veterans' programs, or other factors.

\footnotetext{
${ }^{2}$ See also Paloyo et al. (2010) for an analysis of the effect of military bases on local crime rates.
} 
We contribute to this literature, therefore, by examining the effects of military service on crime using the exogenous variation provided by Australia's Vietnam-era conscription lotteries. Between 1965 and 1972, 15 biannual birth cohorts were subjected to conscription lotteries, conducted by date of birth (DOB). No one from the last three of these cohorts was deployed (Ville and Siminski 2011). ${ }^{3}$ Returns to formal employment for Australian Vietnam veterans are greatly reduced by the veterans' compensation system, much more so than in the US (Siminski 2010). The time allocation model of Ehrlich (1973) predicts that this should increase property crime. ${ }^{4}$ However, many other potential mechanisms are involved, as discussed above and in more detail below.

We draw on a near universe of criminal cases with male defendants that were heard in a 17 -year period (1994-2010) in New South Wales (NSW), Victoria (VIC) and Queensland (QLD), representing nearly 500,000 alleged offenses. These three states constitute over three quarters of the Australian population. Using various specifications, we consistently find no evidence that military services affects crime perpetration rates, at least not in the long run. In our preferred specification, the $95 \%$ confidence interval rules out any positive (negative) crime effects larger than $11 \%(10 \%)$ relative to the mean rate. We also find no evidence of effects on specific categories of crime, including violent crime, non-violent crime and property crime.

${ }^{3}$ A $16^{\text {th }}$ birth cohort also was subjected to a National Service lottery in September 1972. However, the conscription system was abolished before they were due to be called up. Thus we ignore the $16^{\text {th }}$ cohort.

${ }^{4}$ One interesting aspect of the Australian veterans' benefits system is that the reduced incentive to engage in formal work is fully compensated by generous pensions. Very large negative employment effects are accompanied by a zero average effect on income (Siminski and Ville 2012; Siminski 2013). Thus veterans have much more free time to potentially allocate to illegal activity. But any such illegal activity is not motivated by poverty. 
The remainder of the paper is organized as follows. Section 2 briefly outlines the potential mechanisms linking military service to crime, as proposed in economic theories of crime, as well as in criminological and psychiatric literature. Section 3 describes the context of Australian National Service in the Vietnam era. Sections 4 and 5 outline methods and data respectively. The results are presented in Section 6, and Section 7 concludes.

\section{The Mechanisms Linking Military Training to Crime}

In this section we briefly outline the theoretical mechanisms linking military service and crime. We first consider mechanisms motivated by economic theory and then discus other mechanisms. An extensive literature founded by Becker (1968) and Ehrlich (1973) posits crime as rational behavior, that may respond to economic incentives. Individual decisions are based on a perceived payoff from crime, balanced against its costs derived from the risk of capture, conviction, and the nature and severity of punishment. Fines, the loss of labor market experience from a custodial sentence, and reputational damage for employability together form part of this calculus. Overall conditions in the labor market, and the specific opportunities of individual workers, will affect the decision to undertake illegal activity. The empirical research suggests that the relationship is strongest for property crime and robbery, but is weaker for violent crimes (Mustard 2010: 356).

Military service may affect rational choice about crime through numerous mechanisms:

(i) Time spent in military service reduces one's potential civilian labor market experience. If military experience is less valued in the civilian labor market, then it will reduce one's potential earnings in legal work, thus reducing the opportunity cost of illegal activity. On the other hand, military training may enhance human capital. Specific technical skills, as well as cultural aspects of the military, including self-discipline and teamwork, may be rewarded in the labor market. 
Subsidized education for veterans, for example the U.S. GI Bill, also increases wages in formal work. So far, the international empirical evidence on the effect of military service on potential earnings is mixed - many studies find no effect, whilst some find negative and some find positive effects (see the review in Card and Cardoso 2012).

(ii) Veterans' compensation may affect incentives to engage in crime. Veterans' disability pensions are intended to support those whose labor market prospects have been affected by a service-related disability. Yet concerns have been raised about the work disincentives associated with such benefits (Angrist et al. 2010; Autor et al. 2011; Siminski 2013). These benefits could also have non-incentive effects on crime, especially through poverty alleviation. For Australian Vietnam veterans, the work disincentive associated with disability compensation is large. This has resulted in a very large negative employment effect for deployed veterans in 2006 of around 37 percentage points (Siminski 2013). These veterans therefore had much more non-committed time on their hands, which increased the potential for them to engage in illegal activity. While the compensation system does not appear to have affected income on average, it has compressed the income distribution of veterans considerably (Siminski and Ville 2012). This potentially may decrease crime through a poverty alleviation mechanism. ${ }^{5}$

(iii) Military training in the use of weapons and physical combat could enhance a veteran's productivity in committing crimes and thus raise the potential payoff to crime. Social capital networks also may facilitate access to such weaponry.

(iv) Military experience may reduce risk aversion, which in turn would increase the expected utility of criminal behavior.

\footnotetext{
${ }^{5}$ Veterans' compensation may also affect crime negatively if payment eligibility is affected by criminal convictions. In Australia, disability compensation payments are unaffected by criminal convictions. Veterans' income support (including the service pension), however, is not paid while a person is imprisoned, similarly to related civilian pensions.
} 
While economic theory stresses the rational choice aspects of crime, an alternate psychological perspective, common among criminologists, holds that a certain class of individuals pursue a life of crime as a result of the formative behavioral influences in their life. Influences such as family background and exposure to particular events can adversely impact personality traits, especially agreeableness, which may induce a proclivity to illegal behavior. These considerations may be more important than rational crime models for crimes where financial payoffs are less relevant, including acts of violence.

Military service may have psychological effects that affect crime through several mechanisms:

(i) Military training is intended to instil a respect for authority and following rules. Severe punishments and public admonition for misdemeanors may also discourage illegal behavior. Thus military training may increase the direct disutility of committing a crime and/or increase the perceived cost of likely punishment.

(ii) Arkin \& Dobrofsky (1978: 166) suggest that military training involves 'socialization into a masculine domain', which has been associated with muted levels of agreeableness (Jackson et al. 2012) and enhanced levels of violence (Eisenhart 1975). These 'desired' military traits also may be relevant for violent behavior outside the military: masculinity has been identified with sexual violence (Morris 1996); dominance against minority groups (Houdepohl et al. 2010); and violent rather than conciliatory responses to interpersonal conflict (Martin et al. 2000; Wilkowski et al. 2006).

(iii) Spontaneous response training techniques are a component of most military training. Such training prepares recruits to respond (often violently) in situations involving a perceived threat as a way to improve combat effectiveness. This training involves desensitizing recruits to the trauma of violence (including killing). It may translate to violent behavior in latter, civilian life. 
(iv) Conversely, military training aims to foster attributes such as maturity, cooperation, and agreeableness, all of which may be negatively related to crime perpetration.

\section{National Service in Australia}

The Australian conscription ballots resulted in the enlistment of 63,735 National Servicemen ('Nashos'). They served two years of full-time service in the regular army, followed by three years in the reserves. ${ }^{6}$ Their first year consisted largely of training in Australia in three stages: ten weeks of general recruit training, followed by three months with a particular Corps, and finally a similar period training with the assigned unit. The initial stage targeted physical fitness and general military skills. The Corps training focused on the particular skills and operational requirements of a Corps member, whether infantry, tanks, engineering, or artillery. For those units destined for Vietnam, there was further specialized training at the Jungle Training Centre at Canundra (QLD) and participation in group test exercises at Shoalwater Bay (QLD) (Fett et al. 1984; Ham 2007; O'Brien 1995). This was similar in length and nature to the American training for Vietnam (Glenn 2000: 52-5).

The recruits were expected to achieve proficiency in driving, navigation, communication, simple engineering, and first aid, along with a set of specific Corps functions. Most of the skills were designed to support the servicemen in combat, but other time in training was more directly related to battle, including weapons handling and marksmanship. Thus, only a limited amount of time was dedicated to activities that were likely to make men productive and aggressive criminals and more time was devoted to valuable legal employment skills. Moreover, the desensitizing

\footnotetext{
${ }^{6}$ In 1971, the full-time component was reduced to 18 months, with the army-reserve period raised to 3.5 years. In December 1972, all requirements of conscripts were cancelled by a new government.
} 
spontaneous-fire techniques that were taught to American soldiers in Vietnam were largely rejected by the Australian Military Board (Australian War Memorial 1969).

Describing the training experience, conscripts' memoirs describe intense hard work, overlain with verbal abuse, including sexual innuendo and sometimes xenophobic language. The conscripts believed the training was designed to mitigate their sense of individualism (Rintoul 1987: 19). While this environment clearly bred a sense of masculinity, physical assertiveness in military tasks, and self-confidence, it translated less obviously into adversarialism and aggression beyond the military. Certain positive aspects of the training offset the more egregious characterizations, for example: building self-discipline, leadership, friendship, camaraderie, and team work (Donnelly 2001: xi, 94; Ham 2007: 174; Rintoul 1987: 13). Both teamwork and strong character were mentioned explicitly among the goals of training (Australian War Memorial 1970).

After training, most conscripts served their time in Australia; only 18,654 (29 percent) spent part of their service, typically one year, in Vietnam. Of these, only a small number were directly exposed to combat. Drawing upon their experiences in Malaya in the 1950s, the Australians trained for and conducted a war of less overt aggression and more counter-insurgency stealth than their American counterparts (Longley 2008: 67; Westheider 2007: 61). This required careful marksmanship, jungle patrols, and occasional ambushes (McNeill 1984: 195). It emphasized minor engineering skills, such as using winches, searching for tunnels, and maintaining functioning weapons in humid conditions. As the war developed, pacification skills - working in close contact with the Vietnamese civilian population - also were needed, along with the trade skills necessary to help rebuild the damaged community infrastructure. Australian training syllabi included languages and culture and provided advice on relations with the Vietnamese people: 'troops must not only be trained to operate effectively against their enemies in the field, they must also be taught to play their part correctly in ....the campaign to win the support of the people. ..., a willingness to co-operate, to share resources with civilian agencies and to behave 
sympathetically towards the people of the country.' (Australian War Memorial, 'Quelling Insurgency').

\section{Methods}

The empirical approach that we adopt exploits the randomness of the conscription lotteries. It is similar to recent Australian research (Siminski and Ville 2011, 2012; Siminski 2013), which in turn is based on related US work (some examples are Angrist 1990; Lindo and Stoecker 2014, amongst others).

Our aim is to estimate the effect of army service on various measures of individual crime perpetration. Crime perpetration $(y)$ by person $i$ in birth cohort $j$ is expressed in equation (1) as a linear function of army training $(r)$, birth cohort fixed-effects $(\alpha)$ and other individual-level determinants of crime perpetration $(\mu)$.

$y_{i j}=\beta r_{i j}+\alpha_{j}+\mu_{i j}$

$\beta$ is the causal parameter of interest. If army service had been randomly assigned within birth cohorts, OLS estimation of (1) would yield unbiased estimates of $\beta$. Despite the conscription lotteries, army service was not randomly assigned. In particular, many potential conscripts were screened-out in the medical examination, while many 'balloted-out' men joined the army voluntarily. Therefore, $r$ is almost certainly correlated with $\mu$ and OLS estimation of (1) would likely yield biased and inconsistent estimates of $\beta$.

Adding control variables is not a satisfactory solution, because some determinants of crime perpetration are inevitably unobservable. Instead, we use 2SLS. The (binary) conscription lottery 
ballot outcome ( $z$ ) is a randomly assigned source of variation in the probability of army service. ${ }^{7}$ z could be used as a single instrument for army service in a just-identified first-stage regression. Instead, we allow the effect $(\pi)$ of the ballot outcome to vary between birth cohorts:

$r_{i j}=\pi_{j} z_{i j}+\gamma_{j}+\varepsilon_{i j}$

Equations (1) and (2) specify an over-identified 2SLS model, where $\pi_{j}$ is the (first-stage) effect of ballot outcome on the probability of army enlistment for men in birth cohort $j$. This approach yields more precise estimates than the just-identified alternative, because the effect of the ballot outcome on the probability of being enlisted in the army varies between cohorts. ${ }^{8}$

In our preferred analysis, we use data for full set of 15 birth cohorts (men born between January 1945 and June 1952). Then we repeat the analysis using the same specification, with the sample restricted to the three youngest cohorts (men born between January 1951 and June 1952), in an attempt to estimate the effect of peacetime service - because conscripts from these cohorts were not deployed to Vietnam, or to any other combat area.

We also produce a third set of estimates, again using all 15 cohorts, in a specification that separately identifies the effect $\left(\beta_{r}\right)$ of army training and the additional effect $\left(\beta_{v}\right)$ of deployment to Vietnam ( $v)$. Here, the substantive equation is:

$y_{i j}=\beta_{r} r_{i j}+\beta_{v} v_{i j}+\alpha_{j}+\mu_{i j}$

\footnotetext{
${ }^{7}$ The "ballot outcome" is the outcome of the relevant conscription lottery drawing. A man is considered to be "balloted-in" if his DOB was drawn in the ballot held for his birth cohort, and "balloted-out" otherwise. Being "balloted-in" is referred to as "draft eligible" in the American literature.

${ }^{8}$ Using just-identified models, the standard errors of the key estimates are approximately $5 \%$ (1\%) larger for the 15-cohort (3-cohort) specification.
} 
where $r$ and $v$ are both endogenous and both instrumented by the same set of 15 IVs (the ballot outcome in each cohort). This strategy relies on the fact that the probability of deployment varied considerably between cohorts of conscripts.

In each specification, individual-level data needed to estimate the second-stage regression are not available. However, a group-means approach yields identical point estimates to that of individual data, as well as consistently estimated standard errors (Angrist 1991; Angrist and Pischke 2009). Here, each group is an exact DOB. For example, the 2SLS estimates that correspond to the specification in equation (1) are obtained by GLS estimation of:

$\bar{y}_{d j}=\beta \bar{r}_{z j}+\alpha_{j}+\mu_{d j}$

Each observation in (4) is an exact DOB, denoted by the subscript $d, \bar{y}_{d j}$ is the mean number of crimes committed by men with a given DOB; and $\bar{r}_{z j}$ is the proportion of men who served in the army, by ballot outcome and birth cohort. In other words, $\bar{r}_{z j}$ is the predicted value from (2). The GLS weights are equal to the number of men with each DOB. Robust standard errors are shown in the results for each specification.

\section{Data Construction}

The first-stage individual-level database contains the universe of men in the relevant birth cohorts who were in Australia at age 20. It is described in detail in Siminski (2013). It was constructed from military personnel records and official population estimates from the 1960s and 1970s. Because recent migrants cannot be excluded from the second-stage (crime) database, the first-stage data also include synthesized records for migrants who arrived in Australia after the age of 20, in proportion to their fraction of each age cohort in 2006 (as recorded in Census data). This approach is for consistency with the second-stage data and was also used in Siminski 
(2013) and (Siminski and Ville 2012) whenever recent migrants were not identifiable, and hence could not be excluded from the second-stage data.

To construct the second-stage database, we draw on administrative data from cases heard during 1994-2010 in the criminal courts of New South Wales, Victoria, and Queensland. These three largest Australian states contain over $77 \%$ of the Australian population. During those years, our study population was middle-aged (41-65 years). The absence of data for earlier periods has a number of implications for the analysis. Whilst we would like to also study short-run effects, we can only identify long-run effects on crime. Further, crimes induced in the short run themselves may prevent later crimes, particularly through incapacitation due to incarceration, or through stronger deterrence attributable to harsher penalties for repeat offenders. ${ }^{9}$ Finally, it affects the precision of our estimates, because crime rates are highest at younger age groups. ${ }^{10}$ However, this is reflected in the standard errors of our estimates; but we believe they are precise enough to be meaningful, because the data still include a substantial number of crimes.

\footnotetext{
${ }^{9}$ We think this is likely to be only a minor threat to validity. The incarceration rate of Australian men in these age groups is $0.23 \%$ (ABS 2013), almost 5 times lower than in the United States (Guerino et al. 2012). Further, such a dynamic requires the existence of short-run effects. As we have discussed, the international literature on the crime-effects of service has produced mixed results, and there is no data on short-run effects for Australia.

${ }^{10}$ While crime rates are highest at younger ages, the types of crimes committed by males do not differ greatly by age, at least not for offenses that are brought to court. The largest differences are between males under age 20 and over 20 (see for example ABS 2014: Table 5). However, middle-aged male defendants are somewhat less likely to be tried for robbery, unlawful entry, theft, property damage or public order offenses, and more likely to be tried for traffic/vehicle offences and sexual assault.
} 
One limitation of data from the courts is the exclusion of crimes that were committed but not prosecuted. This may bias our estimates (downwards) if veterans are more effective at avoiding arrest conditional on committing a crime, or if police are more lenient with veterans after they have been identified as potential perpetrators. We have no data that can shed light on these threats to validity. Our results are not sensitive to the inclusion of cases with not-guilty verdicts, although these are outnumbered around 5:1 by cases with a guilty verdict.

As shown in Table 1, the data include 490,882 criminal offenses with male defendants born between January 1945 and June 1952; 337,308 of them received guilty verdicts. Table 1 also shows the distribution of these offenses, by state and by crime category, using the Australian Standard Classification Offence Classification (ASOC) Divisions (ABS 2008). There is no standard definition of violent crime in ASOC. As shown in Table 1, we classify crimes in ASOC Divisions 1-4 and Division 6 as 'violent'. Table 1 also shows that most (92\%) of such violent crimes fall into two divisions: 'acts intended to cause injury' (mostly assault) and 'sexual assault and related offenses'.

[Table 1 about here]

In our preferred specifications, the offenses are grouped into cases; 164,211 of them involve at least one guilty verdict. ${ }^{11}$ Some $11 \%$ of these are violent crimes; over one quarter $(29 \%)$ are for

\footnotetext{
${ }^{11}$ A case is a set of one or more offenses heard on the same date for the same defendant. Our results are not sensitive to analyzing offenses rather than cases, but they are less precise because the distribution of the number of offenses within cases is highly skewed.
} 
drunk driving; and 13\% are property crimes. ${ }^{12}$ Some 7,748 cases $(5 \%)$, most them non-violent, resulted in imprisonment.

With some exceptions, these data contain the universe of offenses heard by criminal courts in these states over this period. However, the coverage window begins in mid-1994 for Queensland and in 1995 for Victoria. Further, the QLD data prior to 2001 do not include cases heard in provincial courts. Still, there is no reason to suspect that such missing data would disproportionately affect balloted-in or balloted-out men, thus introducing bias. And in any case, the results are not sensitive to the exclusion of pre-2001 QLD data, or indeed to the exclusion of QLD overall.

Figure 1, which shows the frequency counts of criminal cases with at least one guilty verdict by state and year, illustrates the likely extent of missing pre-2001 data in QLD. It also shows a general downward trend for each state, consistent with the aging of the study population.

[Figure 1 about here]

We combine the crime data with the total counts of men living in NSW, QLD, and VIC, grouped by exact DOB as reported in the 2006 Census. For each DOB, we construct a set of outcome variables equal to the ratio of various crime counts to the number of men. Across DOBs, the mean ratio of (guilty) criminal cases to men living in these states is 0.26 , as illustrated further in the next section.

\footnotetext{
${ }^{12}$ The ASOC codes for drunk driving offenses are 411 and 1431. Property offenses have 4-digit ASOC codes ranging from 0600 to 1030 . They include robbery, extortion and related offenses; unlawful entry with intent/burglary, break and enter; theft and related offenses; fraud, deception and related offenses; and illicit drug offenses (excluding possession, use or miscellaneous drug offenses).
} 


\section{Results}

\subsection{First-stage Results}

The first-stage regression results are shown in Table 2. The upper panel reports estimates from the preferred specification, using the full sample drawn from all fifteen 6-month birth cohorts. The lower panel shows the corresponding results with the sample restricted to the three nondeployed birth cohorts. In each case, the ballot outcome effect is allowed to vary between birth cohorts; therefore, the models are over-identified.

[Table 2 about here]

Two first-stage regressions were estimated for the full sample: one for (any) army service and one for deployed service (to Vietnam). The ballot outcome is a strong predictor of army service for each birth cohort, inducing between 10 and 25 percent of balloted-in men into the army. ${ }^{13}$ For all but the youngest three cohorts, the ballot outcome is also a strong predictor of deployment to Vietnam.

In each regression, the first-stage relationships are very strong, as shown by the various firststage F-statistics reported, all of which exceed 900.

\subsection{Visual Presentation of Reduced-Form Results}

Figure 2 graphically summarises the reduced-form relationship between ballot-outcome and crime. Much of the intuition of the results, including the precision of the estimates, is conveyed through this Figure. It shows the ratios of crimes committed to population, by birth cohort and

\footnotetext{
${ }^{13}$ The coefficients on the instruments are smaller than those previously reported (for example in Siminski 2013), which reflects the inclusion of recent migrants in the data here.
} 
ballot outcome. Panel A includes all crimes. The other panels show the corresponding results for specific sub-sets of crimes.

[Figure 2 about here]

In each panel, there is an upward trend from left to right, probably because the data availability window covers a different age range for each cohort. For example, the data include crimes at approximately ages 49-66 for the oldest cohort (shown on the left side of each Panel), and for ages 41-58 for the youngest cohort.

In Panel A, the difference in crime rates between balloted-in and balloted-out DOBs is small for each cohort and is sometimes positive, but often negative. This suggests that any effects of army service on crime likely will be small, but precisely estimated. Comparing the crime rates of balloted-in to balloted-out men in the three non-deployed cohorts (on the far right), the rate is lower among balloted-in men in two of the cohorts, and almost equal in the third.

The other panels show similar patterns to those of Panel A, differing primarily in the extent of variation, likely reflecting the volume of crimes in each category. For example, the last four panels show the results for crimes resulting in imprisonment, and are derived from relatively few cases.

\subsection{SLS estimates}

Our main results are presented in Table 3. It shows the estimates from nine separate 2SLS models, differing only in the types of crime included in the dependent variable. Each model uses an over-identified specification, where the (first-stage) effect of ballot outcome on army service 
is allowed to vary between cohorts, ${ }^{14}$ and the full sample of 15 conscription-eligible birth cohorts is used. The mean of the dependent variable is shown in each panel, along with the estimated coefficients and their robust standard errors. However, it is the results in the three columns at the right side of the table that are of primary interest. They express the point estimates and 95\% confidence interval bounds as percentages relative to the mean of the dependent variable. These assist us in interpreting the magnitude and precision of our estimates.

[Table 3 about here]

Panel A shows the key result, for all crimes combined. The estimate shows no evidence that army service affects crime. The point estimate is close to zero and the confidence interval is reasonably small. It rules out positive effects larger than $11 \%$ relative to the mean. It also rules out negative effects larger than $10 \%$ relative to the mean.

The estimates for violent crime (Panel B), non-violent crime (Panel C), and property crime (Panel D) are all similar, differing only in their precision. In each case, the estimates are quite close to zero. The confidence interval for violent crime ranges from $-21 \%$ to $19 \%$. For property crime, it ranges from $-21 \%$ to $22 \%$. For drunk driving, the point estimate is $5 \%$, with a confidence interval ranging from $-8 \%$ to $18 \%$.

The lower four panels show the results for crimes resulting in imprisonment. There are fewer such crimes, so these results are less precise. In each category the point estimates are negative, except for violent crimes resulting in imprisonment. The only estimate that is close to being statistically significant is for non-violent crimes resulting in imprisonment; the p-value is 0.095 . Overall, these results suggest that army service has neither large positive nor large negative effects on crime.

${ }^{14}$ The estimates from the just-identified specifications are similar to those from the overidentified specifications, but are slightly less precise. 
We then repeat the analysis with the sample restricted to non-deployed birth cohorts (Table 4). Here the point estimates are negative for every type of crime and often are large, but none are statistically significant at the $10 \%$ level. For all crimes combined, the confidence interval ranges from $-44 \%$ to $20 \%$. For violent crimes, the confidence interval is $-79 \%$ to $26 \%$; for property crimes the interval ranges from $-87 \%$ to $30 \%$. These estimates rule out any large positive effects of non-deployed service on crime.

[Table 4 about here]

We further explore the role of deployment in Appendix Table A.1, which shows the results from models in which army service and deployment both are included as endogenous variables. The results there are consistent with those shown in Table 4. The coefficients of (non-deployed) service are negative for most types of crime, but are never statistically significant. For all crimes combined, the confidence interval ranges from $-29 \%$ to $25 \%$ of the mean. The estimated effects of deployment also are statistically insignificant in each model, but the confidence intervals are wide.

\section{Conclusion}

Recent research into the effects of military service on criminal behavior in later life has generated a mixed set of results. We contribute to this literature using the exogenous variation provided by Australia's conscription lotteries. We find no evidence of long-run effects of service on crime overall, or for violent crime, property crime, or for any other categories of crime.

Our results come with some caveats and may not necessarily apply in other contexts. In particular, the criminal offense data we analyse only cover the study population's middle-age years. Although young males have higher crime rates, we believe that our estimates are precise 
enough to be meaningful. Nevertheless, we cannot test for crime effects that occur shortly after army service. However, we can rule out any substantial 'permanent' effects. ${ }^{15}$

In order to better understand the diverse results that have been found across countries, we suggest that future research could place greater emphasis on cross-country similarities and differences. Our results are contingent on the specific context of Australian conscript training, and the nature of deployed service, veterans' programs and other institutions. National Service in Australia lasted for two years at most, among men who were mainly 20 years old when they enlisted. Their training involved character shaping with positive as well as potentially negative elements. Training skills were wide, varied, and often unrelated to acts of combat. Even among those not deployed to Vietnam, recruits were prepared for a war of covert counter-insurgency rather than for large-scale battles. This training may have been less realistic or desensitizing than in the United States, because live rounds and 'Quick Kill' training techniques were not used. Australian training also included 'softer' pacification skills, motivated by the need for close cooperation with Vietnamese civilians in Australia's role in the war.

[Table A.1 about here]

\section{References}

ABS (2008), Australian Standard Offence Classification (ASOC), 2008 (2nd Edition) ABS Catalogue No. 1234.0 (Canberra: Australian Bureau of Statistics).

--- (2013), Prisoners in Australia, 2012 Reissue ABS Catalogue No. 4517.0 (Canberra: Australian Bureau of Statistics).

\footnotetext{
${ }^{15}$ The violent crime effects that Lindo \& Stoecker (2014) find are statistically significant only for periods soon after military service. Similar to our results, their estimates for later periods are statistically insignificant.
} 
--- (2014), Criminal Courts, Australia, 2012-13, ABS Cat. No. 4513.0 (Canberra: Australian Bureau of Statistics).

Albæk, Karsten, et al. (2013), Does Peacetime Military Service Affect Crime? (IZA Discussion Paper No. 7528$)$.

Anderson, D Mark and Rees, Daniel (forthcoming), 'Deployments, Combat Exposure, and Crime', Journal of Law and Economics.

Angrist, Joshua D. (1990), 'Lifetime Earnings and the Vietnam Era Draft Lottery: Evidence from Social Security Administrative Records', American Economic Review, 80 (3), 313-36.

--- (1991), 'Grouped-data estimation and testing in simple labor-supply models', Journal of Econometrics, 47, 243-66.

Angrist, Joshua D. and Pischke, Jorn-Steffen (2009), Mostly Harmless Econometrics (Princeton: Princeton University Press).

Angrist, Joshua D., Chen, Stacey H, and Frandsen, Brigham R (2010), 'Did Vietnam Veterans Get Sicker in the 1990s? The Complicated Effects of Military Service on Self-Reported Health', Journal of Public Economics, 94, 824-37.

Arkin, W and Dobrofsky, L (1978), 'Military socialization and masculinity', Journal of Social Issues, 34, 151-68.

Australian War Memorial 'Quelling insurgency', (in Papers from 1RAR relating to operations in Vietnam. AWM 87/016).

--- (1969), 'Training-specific weapons', (AWM 98 R852.19.1).

--- (1970), 'Training Information Report', (AWM 98 723.1.12.5).

Autor, David H, Duggan, Mark G, and Lyle, David S (2011), 'Battle Scars? The Puzzling Decline in Employment and Rise in Disability Receipt among Vietnam Era Veterans', American Economic Review: Papers \& Proceedings, 101 (3), 339-44.

Becker, Gary S. (1968), 'Crime and Punishment: An Economic Approach', The Journal of Political Economy, 76 (2), 169-217. 
Card, David and Cardoso, Ana Rute (2012), 'Can Compulsory Military Service Raise Civilian Wages? Evidence from the Peacetime Draft in Portugal', American Economic Journal: Applied Economics, 4 (4), 57-93.

Donnelly, R (2001), The Scheyville Experience. The Officer Training Unit, Scheyville 1965-73 (St Lucia: University of Queensland Press).

Ehrlich, Isaac (1973), 'Participation in Illegitimate Activities: A Theoretical and Empirical Investigation', The Journal of Political Economy, 81 (3), 521-65.

Eisenhart, R (1975), 'You can't hack it little girl: a discussion of the covert psychological agenda of modern combat training', Journal of Social Issues, 31, 13-23.

Fett, MJ, et al. (1984), The Mortality Report, 3 vols. (Australian Veterans Health Studies; Canberra: AGPS).

Galiani, Sebastian, Rossi, Martín A., and Schargrodsky, Ernesto (2011), 'Conscription and Crime: Evidence from the Argentine Draft Lottery', American Economic Journal: Applied Economics, $3(2), 119-36$.

Glenn, R (2000), Reading Athena's Dance Card. Men Against Fire in Vietnam (Annapolis, MD: Naval Institute Press).

Guerino, Paul, Harrison, Paige M., and Sabol, William J. (2012), Prisoners in 2010 (Bureau of Justice Statistics).

Ham, P (2007), Vietnam. The Australian War (Sydney: Harper Collins).

Houdepohl, A, Parrott, D, and Zeichner, A (2010), 'Heterosexual men's anger in response to male homosexuality: effects of erotic and non-erotic depictions of male-male intimacy and sexual prejudice', Journal of Homosexuality, 57, 1022-38.

Jackson, J, et al. (2012), 'Military training and personality trait development: does the military make the man, or does the man make the military', Psychological Science, 23, 270-77.

Lindo, Jason M and Stoecker, Charles (2014), 'Drawn into Violence: Evidence on 'What Makes a Criminal' from the Vietnam Draft Lotteries', Economic Inquiry, 52 (1), 239-58. 
Longley, K (2008), Grunts. The American Combat Soldier in Vietnam (Armonk, NY: M.E. Sharpe).

Martin, R, Watson, D, and Wan, C (2000), 'A three-factor model of trait anger: dimensions of affect, behaviour, and cognition', Journal of Personality, 65, 869-97.

McNeill, I (1984), The Team: Australian Army Advisers in Vietnam (Canberra: Australian War Memorial).

Morris, M (1996), 'By force of arms: rape, war and military culture', Duke Law Journal, 45, 651781.

Mustard, David B (2010), 'Labor markets and crime: new evidence on an old puzzle', in Bruce L. Benson and Paul R. Zimmerman (eds.), Handbook on the Economics of Crime (Cheltanham: Edward Elgar).

O'Brien, M (1995), Conscripts and Regulars with the Seventh Battalion in Vietnam (St Leonards, NSW: Allen \& Unwin).

Oi, Walter Y (1967), 'The Economic Cost of the Draft', American Economic Review, 57 (2), 39-62.

Paloyo, Alfredo, Vance, Colin , and Vorell, Matthias (2010), Local Determinants of Crime: Do Military Bases Matter? (Ruhr-Universität Bochum: Ruhr Economic Papers \#211).

Rintoul, S (1987), Ashes of Vietnam. Australian Voices (Richmond, VIC: Heinemann).

Siminski, Peter (2013), 'Employment Effects of Army Service and Veterans' Compensation: Evidence from the Australian Vietnam-Era Conscription Lotteries', The Review of Economics and Statistics, 95 (1), 87-97.

Siminski, Peter and Ville, Simon (2011), 'Long-Run Mortality Effects of Vietnam-Era Army Service: Evidence from Australia's Conscription Lotteries', American Economic Review: Papers \& Proceedings, 101 (3), 345-49.

--- (2012), 'I Was Only Nineteen, 45 Years Ago: What Can we Learn from Australia's Conscription Lotteries?', Economic Record, 88 (282), 351-71. 
Ville, Simon and Siminski, Peter (2011), 'A Fair and Equitable Method of Recruitment? Conscription by Ballot into the Australian Army during the Vietnam War', Australian Economic History Review, 51 (3), 277-96.

Westheider, J (2007), The Vietnam War (Westport, CT: Greenwood Press).

Wilkowski, B, Robinson, M, and Meier, B (2006), 'Agreeableness and the prolonged spatial processing of antisocial and prosocial information', Journal of Research in Personality, 40, 1152-68. 
NSW

VIC

QLD

Total

Offences Heard

$153,074 \quad 183,485 \quad 154,323$

490,882

Offences With a Guilty Verdict by ASOC Division

$\underline{\text { Violent }}$

Homicide and Related Offences (ASOC 01)

$\begin{array}{rrrr}195 & 21 & 63 & 279 \\ 11,463 & 4,038 & 2,757 & 18,258 \\ 2,625 & 3,120 & 4,298 & 10,043 \\ 467 & 1,280 & 361 & 2,108 \\ 117 & 68 & 57 & 242\end{array}$

Robbery, Extortion and Related Offences (06)

Dangerous or Negligent Acts Endangering Persons (04)

Unlawful Entry with Intent/Burglary, Break and Enter (07)

Theft and Related Offences (08)

Fraud, Deception and Related Offences (09)

Illicit Drug Offences (10)

$\begin{array}{rrrr}5,374 & 3,839 & 11,538 & 20,751 \\ 394 & 1,026 & 576 & 1,996\end{array}$

$5,561 \quad 9,867 \quad 4,797 \quad 20,225$

$5,780 \quad 12,986 \quad 9,544 \quad 28,310$

$5,771 \quad 4,814 \quad 5,748 \quad 16,333$

Prohibited and Regulated Weapons and Explosives Offences (11)

3,612

3,540

2,354

9,506

$3,018 \quad 1,275$

1,361

5,654

Public Order Offences (13)

4,430

4,398

9,306

18,134

66,767

33,959

42,673

143,399

Offences against Justice Procedures, Govt Sec \& Govt Ops (15)

9,380

10,695

11,561

31,636

Miscellaneous Offences (16) + Unclassified

2,643

5,708

2,083

10,434

All Offences With a Guilty Verdict

$127,597 \quad 100,634$

109,077

337,308

Cases with at least 1 Guilty Offence

Violent

Non-Violent

Property

Drink-Driving

All Cases with at least 1 Guilty Offence
11,396

57,526

8,910

22,689

68,922
4,336

39,632

7,412

9,289

43,968
$2,943 \quad 18,675$

$48,378 \quad 145,536$

$5,636 \quad 21,958$

$15,229 \quad 47,207$

$51,321 \quad 164,211$

Cases resulting in Imprisonment

Violent
Non-Violent
All Cases resulting in imprisonment

$\begin{array}{llll}1,404 & 589 & 545 & 2,538\end{array}$

$2,506 \quad 1,258 \quad 1,446 \quad 5,210$

$3,910 \quad 1,847 \quad 1,991 \quad 7,748$

Notes: The data contain criminal court cases with male defendants born between January 1945 and June 1952, heard during 1994-2010. 


\begin{tabular}{|c|c|c|c|c|}
\hline \multirow[b]{3}{*}{ Instrumental variable } & \multicolumn{4}{|c|}{ Dependent Variable } \\
\hline & \multicolumn{2}{|c|}{ Army Service $(r)$} & \multicolumn{2}{|c|}{ Deployment to Vietnam $(v)$} \\
\hline & $\begin{array}{c}\text { estimated } \\
\text { coefficient }\end{array}$ & $\begin{array}{l}\text { (robust } \\
\text { standard } \\
\text { error) } \\
\end{array}$ & $\begin{array}{l}\text { estimated } \\
\text { coefficient }\end{array}$ & $\begin{array}{l}\text { (robust } \\
\text { standard } \\
\text { error) }\end{array}$ \\
\hline \multicolumn{5}{|c|}{ Full sample (All 15 Birth Cohorts) } \\
\hline$z * c 1$ & $0.2471^{* * *}$ & $(0.0026)$ & $0.0909^{* * *}$ & $(0.0019)$ \\
\hline $\mathrm{z} * \mathrm{c} 2$ & $0.2377^{* * *}$ & $(0.0031)$ & $0.0908^{* * *}$ & $(0.0022)$ \\
\hline$z * c 3$ & $0.2132^{* * *}$ & $(0.0034)$ & $0.0895^{* * *}$ & $(0.0025)$ \\
\hline$z * c 4$ & $0.2197^{* * *}$ & $(0.0035)$ & $0.1075^{* * *}$ & $(0.0027)$ \\
\hline$z * c 5$ & $0.2030^{* * *}$ & $(0.0033)$ & $0.0971^{* * *}$ & $(0.0025)$ \\
\hline$z * c 6$ & $0.1968^{* * *}$ & $(0.0035)$ & $0.1034^{* * *}$ & $(0.0027)$ \\
\hline$z * c 7$ & $0.2015^{* * *}$ & $(0.0033)$ & $0.0931^{* * *}$ & $(0.0024)$ \\
\hline $\mathrm{z} * \mathrm{c} 8$ & $0.2154^{* * *}$ & $(0.0038)$ & $0.0861^{* * *}$ & $(0.0027)$ \\
\hline z*c9 & $0.2011^{* * *}$ & $(0.0031)$ & $0.0683^{* * *}$ & $(0.0021)$ \\
\hline$z * c 10$ & $0.2036^{* * *}$ & $(0.0040)$ & $0.0468^{* * *}$ & $(0.0023)$ \\
\hline$z * c 11$ & $0.1935^{* * *}$ & $(0.0039)$ & $0.0246^{* * *}$ & $(0.0018)$ \\
\hline$z * c 12$ & $0.1870^{* * *}$ & $(0.0033)$ & $0.0049^{* * *}$ & $(0.0010)$ \\
\hline$z * c 13$ & $0.1681^{* * *}$ & $(0.0027)$ & 0.0004 & $(0.0007)$ \\
\hline$z * c 14$ & $0.1529^{* * *}$ & $(0.0028)$ & 0.0006 & $(0.0006)$ \\
\hline$z * c 15$ & $0.1025^{* * *}$ & $(0.0024)$ & $-0.0010^{* * *}$ & $(0.0004)$ \\
\hline F-stat for IVs & \multicolumn{2}{|c|}{3,833} & \multicolumn{2}{|c|}{947} \\
\hline $\begin{array}{l}\text { Angrist-Pischke } \\
\text { Multivariate F-stat }\end{array}$ & \multicolumn{2}{|c|}{1,860} & \multicolumn{2}{|c|}{919} \\
\hline N & \multicolumn{2}{|c|}{$1,030,740$} & \multicolumn{2}{|c|}{$1,030,740$} \\
\hline \multicolumn{5}{|c|}{ Non-Deployed Sample (Youngest 3 Birth Cohorts) } \\
\hline$z * c 13$ & $0.1681^{* * *}$ & $(0.0027)$ & & \\
\hline$z * c 14$ & $0.1529^{* * *}$ & $(0.0028)$ & & \\
\hline $\mathrm{z} * \mathrm{c} 15$ & $0.1025^{* * *}$ & $(0.0024)$ & & \\
\hline F-stat for IVs & \multicolumn{2}{|c|}{2,844} & & \\
\hline N & \multicolumn{2}{|c|}{210,456} & & \\
\hline
\end{tabular}

Notes: The upper panel reports key estimates from first-stage regressions of army service $(r)$ and deployment to Vietnam $(v)$ on 15 instruments (a binary conscription ballot outcome indicator for each 
birth cohort). The lower panel reports corresponding first-stage regression results for army service and for, using a restricted sample, limited to non-deployed birth cohorts. Each regression includes birth cohort fixed-effects. $* p<0.1, * * p<0.05, * * * p<0.01$ 
Table 3 2SLS Estimates of the Effects of Military Service on Crime (All 15 Birth Cohorts)

\begin{tabular}{|c|c|c|c|c|c|}
\hline \multirow[b]{2}{*}{ Endogenous variable } & \multirow{2}{*}{$\begin{array}{c}\text { mean of } \\
\text { dependent } \\
\text { variable }\end{array}$} & \multicolumn{4}{|c|}{ Estimated 2SLS effects } \\
\hline & & $\begin{array}{l}\text { Point estimates } \\
\text { (robust S.E.s) }\end{array}$ & $\begin{array}{l}\text { Point estimate } \\
\text { as } \% \text { of mean }\end{array}$ & \multicolumn{2}{|c|}{$\begin{array}{c}95 \% \text { CI bounds } \\
\text { as } \% \text { of mean }\end{array}$} \\
\hline & & A. Dependent & riable: All crime & & \\
\hline \multirow[t]{2}{*}{ Army service $(r)$} & 0.264 & $0.001 \quad(0.0144)$ & $0 \%$ & $-10 \%$ & $11 \%$ \\
\hline & \multicolumn{5}{|c|}{$\underline{\text { B. Dependent Variable: Violent crimes }}$} \\
\hline \multirow[t]{2}{*}{ Army service $(r)$} & 0.030 & $(0.0031)$ & $-1 \%$ & $-21 \%$ & $19 \%$ \\
\hline & \multicolumn{5}{|c|}{ C. Dependent Variable: Non-violent crimes } \\
\hline \multirow[t]{2}{*}{ Army service $(r)$} & 0.234 & $0.001 \quad(0.0134)$ & $1 \%$ & $-11 \%$ & $12 \%$ \\
\hline & \multicolumn{5}{|c|}{ D. Dependent Variable: Property crimes } \\
\hline \multirow[t]{2}{*}{ Army service $(r)$} & 0.035 & $0.000 \quad(0.0039)$ & $1 \%$ & $-21 \%$ & $22 \%$ \\
\hline & \multicolumn{5}{|c|}{ E. Drink Driving Crimes } \\
\hline \multirow[t]{2}{*}{ Army service $(r)$} & 0.076 & $(0.0051)$ & $5 \%$ & $-8 \%$ & $18 \%$ \\
\hline & \multicolumn{5}{|c|}{ F. Crimes resulting in Imprisonment } \\
\hline \multirow[t]{2}{*}{ Army service $(r)$} & 0.012 & $-0.002 \quad(0.0024)$ & $-16 \%$ & $-55 \%$ & $22 \%$ \\
\hline & \multicolumn{5}{|c|}{ G. Violent crimes resulting in Imprisonment } \\
\hline \multirow[t]{2}{*}{ Army service $(r)$} & 0.004 & $0.001 \quad(0.0012)$ & $29 \%$ & $-27 \%$ & $85 \%$ \\
\hline & \multicolumn{5}{|c|}{ H. Non-violent crimes resulting in Imprisonment } \\
\hline \multirow[t]{2}{*}{ Army service $(r)$} & 0.008 & $-0.003^{*} \quad(0.0019)$ & $-38 \%$ & $-83 \%$ & $7 \%$ \\
\hline & \multicolumn{5}{|c|}{ I. Property crimes resulting in Imprisonment } \\
\hline Army service $(r)$ & 0.005 & $(0.0014)$ & $-43 \%$ & $-104 \%$ & $17 \%$ \\
\hline
\end{tabular}

Notes: This table shows 2SLS estimates of the effect of army training on subsequent crime perpetration. Each of the nine panels contains results for a particular category of criminal offenses. Cases with one or more guilty verdict are included. The sample includes men from all 15 conscription-eligible birth cohorts (those born between January 1945 and June 1952). A GLS group-means approach is utilised, where the groups are exact dates of birth (DOBs) and the weights are the number of men with each DOB living in NSW, VIC or QLD. In each model, N $=$ 2,738 DOBs, representing 621,283 men. Each model includes birth cohort fixed effects. Robust standard errors are in parentheses. $* p<0.1,{ }^{* *} p<0.05, * * * p<0.01$ 
Table 4 2SLS Estimates of the Effects of Non-deployed Military Service on Crime (NonDeployed Birth Cohorts Only)

\begin{tabular}{|c|c|c|c|c|c|}
\hline \multirow[b]{2}{*}{ Endogenous variable } & \multirow{2}{*}{$\begin{array}{c}\text { mean of } \\
\text { dependent } \\
\text { variable }\end{array}$} & \multicolumn{4}{|c|}{ Estimated 2SLS effects } \\
\hline & & $\begin{array}{l}\text { Point estimates } \\
\text { (robust S.E.s) }\end{array}$ & \multirow{2}{*}{$\begin{array}{l}\text { Point estimate } \\
\text { as } \% \text { of mean } \\
\text { Variable: All crin }\end{array}$} & \multicolumn{2}{|c|}{$\begin{array}{c}95 \% \text { CI bounds } \\
\text { as } \% \text { of mean }\end{array}$} \\
\hline & & A. Dependent & & & \\
\hline \multirow[t]{2}{*}{ Army service $(r)$} & 0.326 & $-0.039 \quad(0.0526)$ & $-12 \%$ & $-44 \%$ & $20 \%$ \\
\hline & \multicolumn{5}{|c|}{ B. Dependent Variable: Violent crimes } \\
\hline \multirow[t]{2}{*}{ Army service $(r)$} & 0.037 & $-0.010 \quad(0.0099)$ & $-26 \%$ & $-79 \%$ & $26 \%$ \\
\hline & \multicolumn{5}{|c|}{ C. Dependent Variable: Non-violent crimes } \\
\hline \multirow[t]{2}{*}{ Army service $(r)$} & 0.288 & $(0.0495)$ & $-10 \%$ & $-44 \%$ & $23 \%$ \\
\hline & \multicolumn{5}{|c|}{$\underline{\text { D. Dependent Variable: Property crimes }}$} \\
\hline \multirow[t]{2}{*}{ Army service $(r)$} & 0.045 & $-0.013 \quad(0.0133)$ & $-29 \%$ & $-87 \%$ & $30 \%$ \\
\hline & \multicolumn{5}{|c|}{ E. Drink Driving Crimes } \\
\hline \multirow[t]{2}{*}{ Army service $(r)$} & 0.091 & $(0.0154)$ & $-27 \%$ & $-60 \%$ & $7 \%$ \\
\hline & \multicolumn{5}{|c|}{ F. Crimes resulting in Imprisonment } \\
\hline \multirow[t]{2}{*}{ Army service $(r)$} & 0.016 & $(0.0083)$ & $-68 \%$ & $-172 \%$ & $36 \%$ \\
\hline & \multicolumn{5}{|c|}{ G. Violent crimes resulting in Imprisonment } \\
\hline \multirow[t]{2}{*}{ Army service $(r)$} & 0.005 & $-0.002 \quad(0.0034)$ & $-41 \%$ & $-190 \%$ & $108 \%$ \\
\hline & \multicolumn{5}{|c|}{$\underline{\text { H. Non-violent crimes resulting in Imprisonment }}$} \\
\hline \multirow[t]{2}{*}{ Army service $(r)$} & 0.011 & $(0.0069)$ & $-78 \%$ & $-201 \%$ & $44 \%$ \\
\hline & \multicolumn{5}{|c|}{ I. Property crimes resulting in Imprisonment } \\
\hline Army service $(r)$ & 0.006 & $-0.001 \quad(0.0051)$ & $-15 \%$ & $-173 \%$ & $143 \%$ \\
\hline
\end{tabular}

Notes: This table shows 2SLS estimates of the effect of non-deployed army service on subsequent crime perpetration. Each of the nine panels contains results for a particular category of criminal offenses. Cases with one or more guilty verdict are included. The sample is restricted to men in the youngest three conscription-eligible birth cohorts (those born between January 1951 and June 1952). Conscripts from these cohorts served only in Australia. A GLS groupmeans approach is utilized, where the groups are exact dates of birth (DOBs) and the weights are 
the number of men with each DOB living in NSW, VIC or QLD. In each model, N $=547$ DOBs, representing 127,478 men. Each model includes birth cohort fixed effects. Robust standard errors are in parentheses. $* p<0.1,{ }^{* *} p<0.05,{ }^{* * *} p<0.01$ 
Figure 1 Frequency Counts of Crimes by State and Year

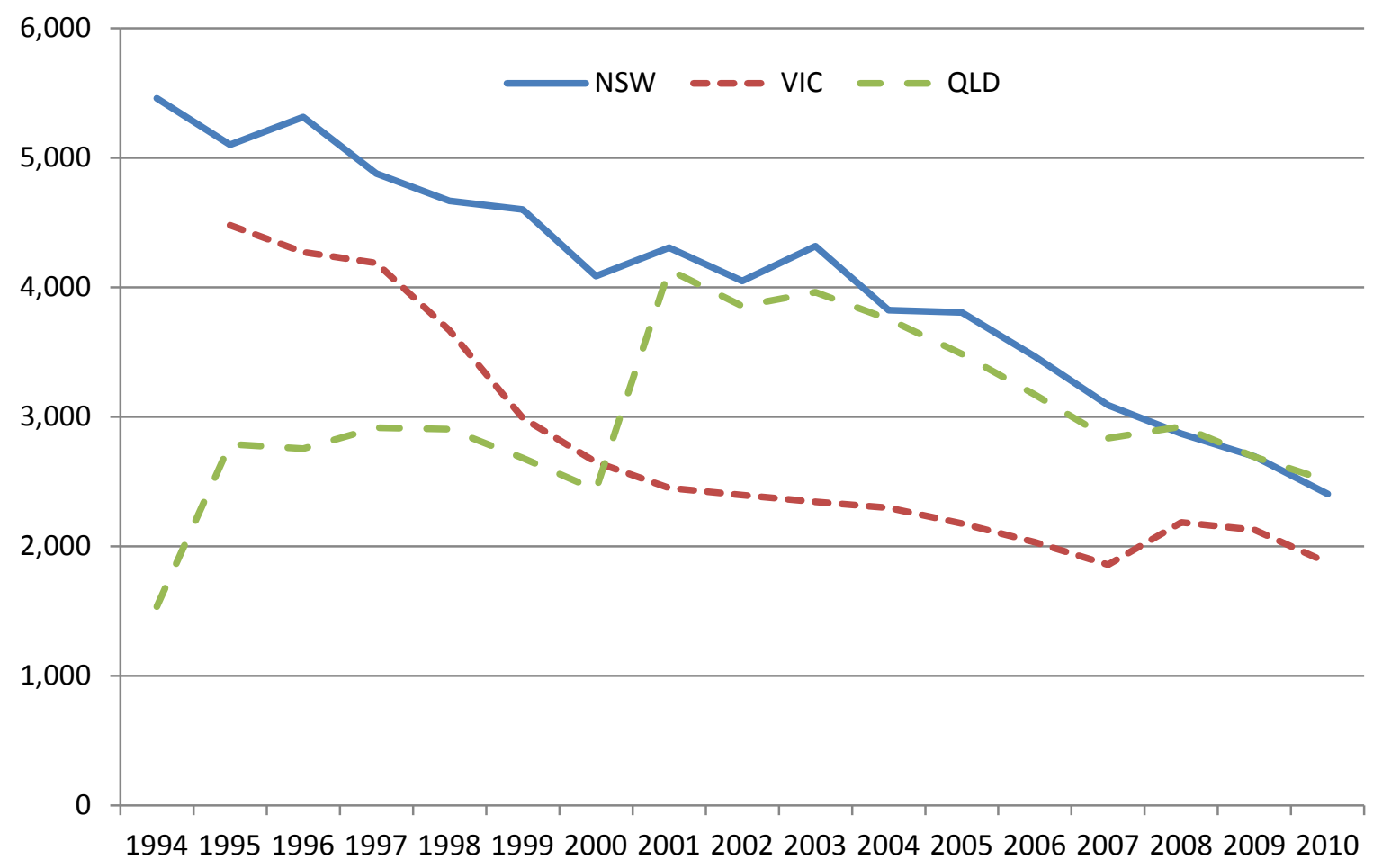

Note: This figure shows annual counts of criminal court cases with at least one guilty verdict, for male defendants born between January 1945 and June 1952, heard during 1994-2010, for each of Australia's three largest states. Data for cases heard prior to 2001 in QLD provincial courts are unavailable. 
Figure 2 Ratios of Crimes Committed to Population by 6-month Birth Cohort and Conscription Ballot Outcome for Various Crime Categories

A. All crimes

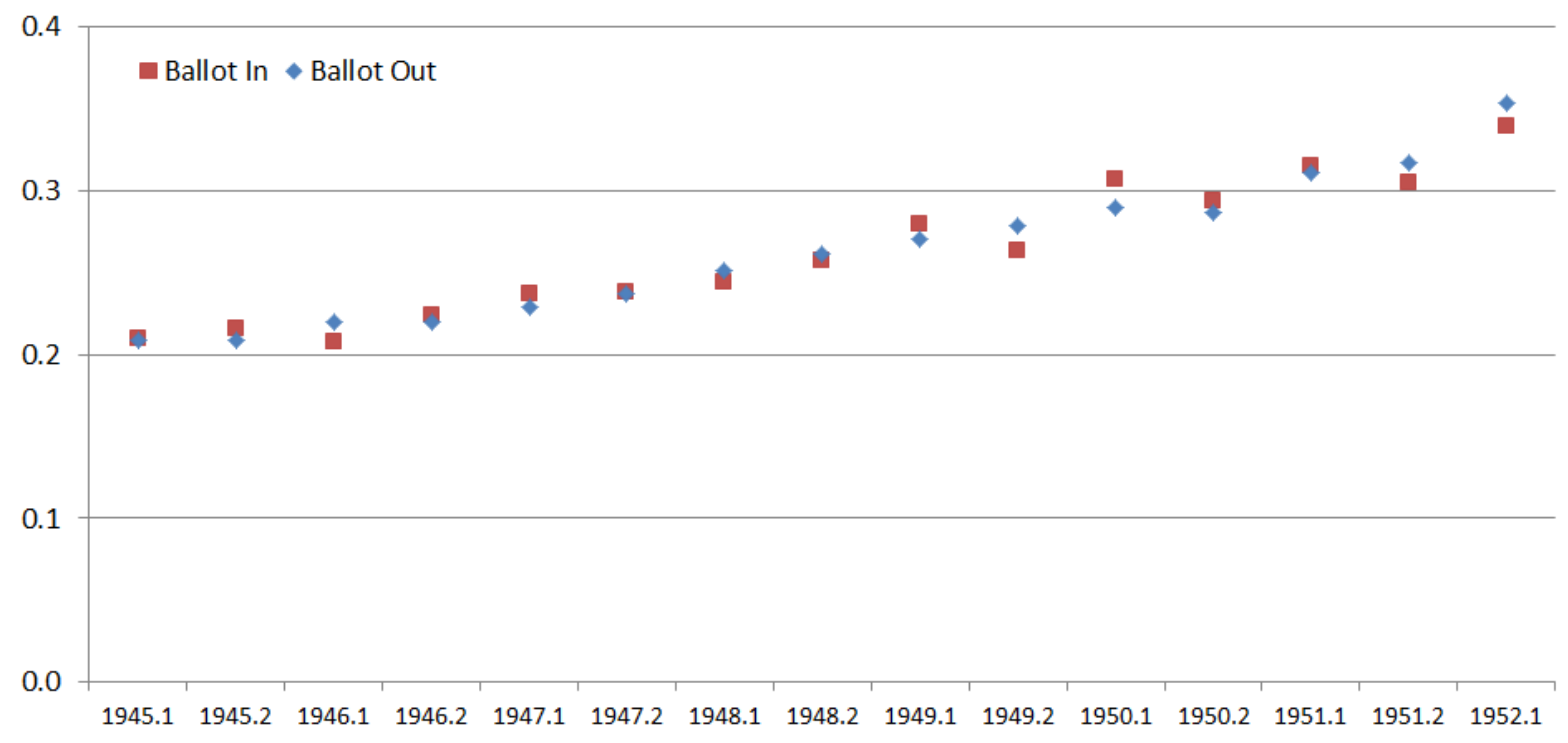

B. Violent crimes

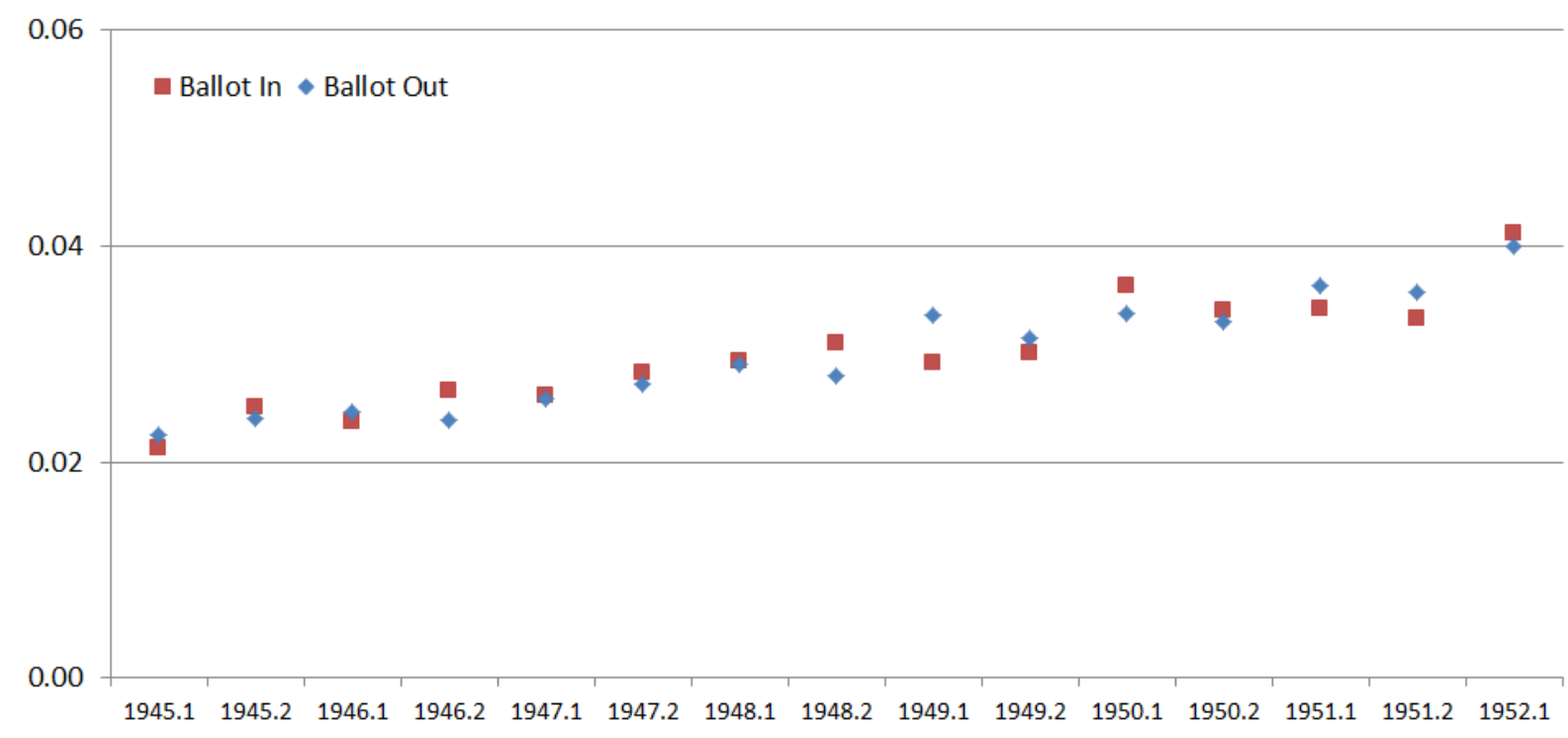


C. Non-violent crimes

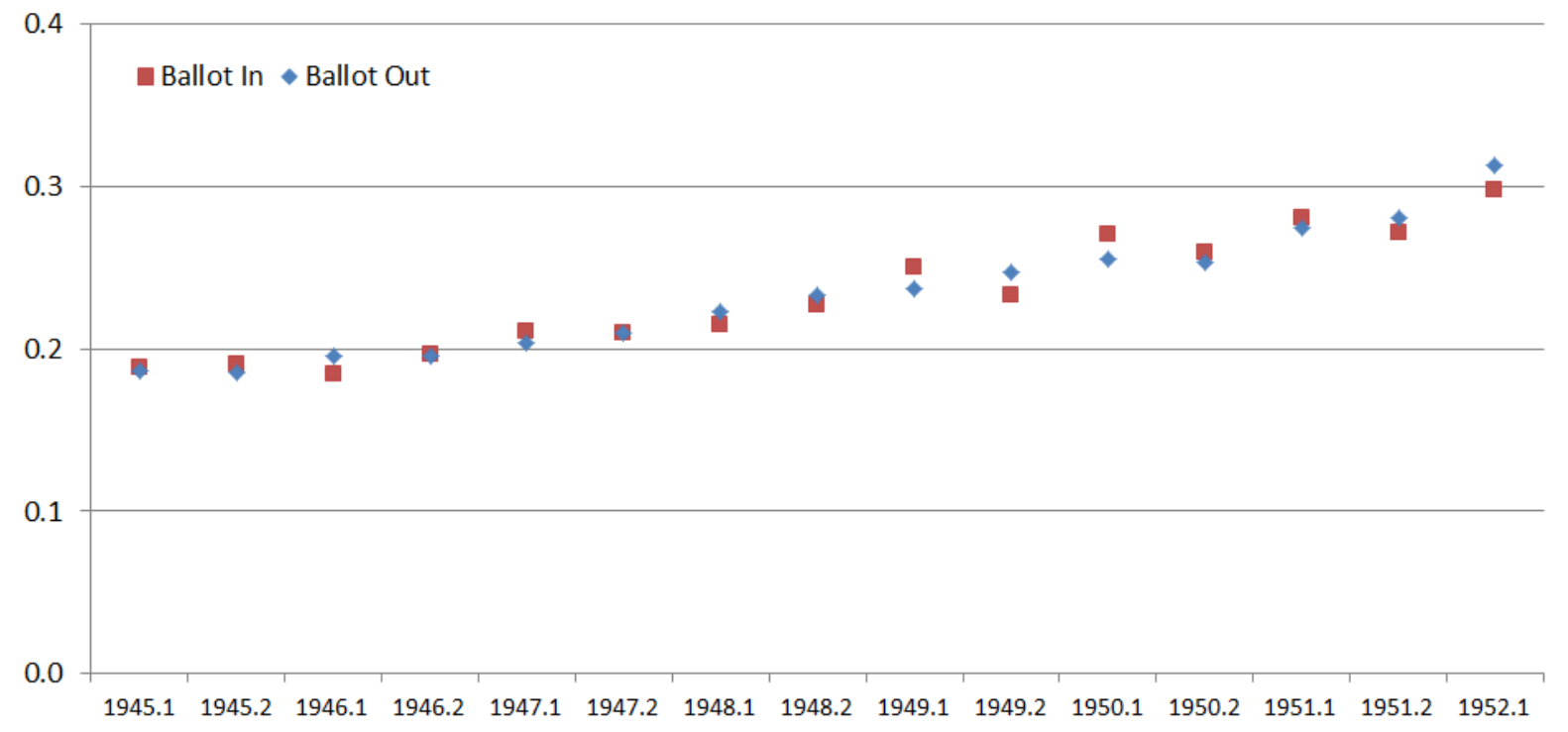

D. Property crimes

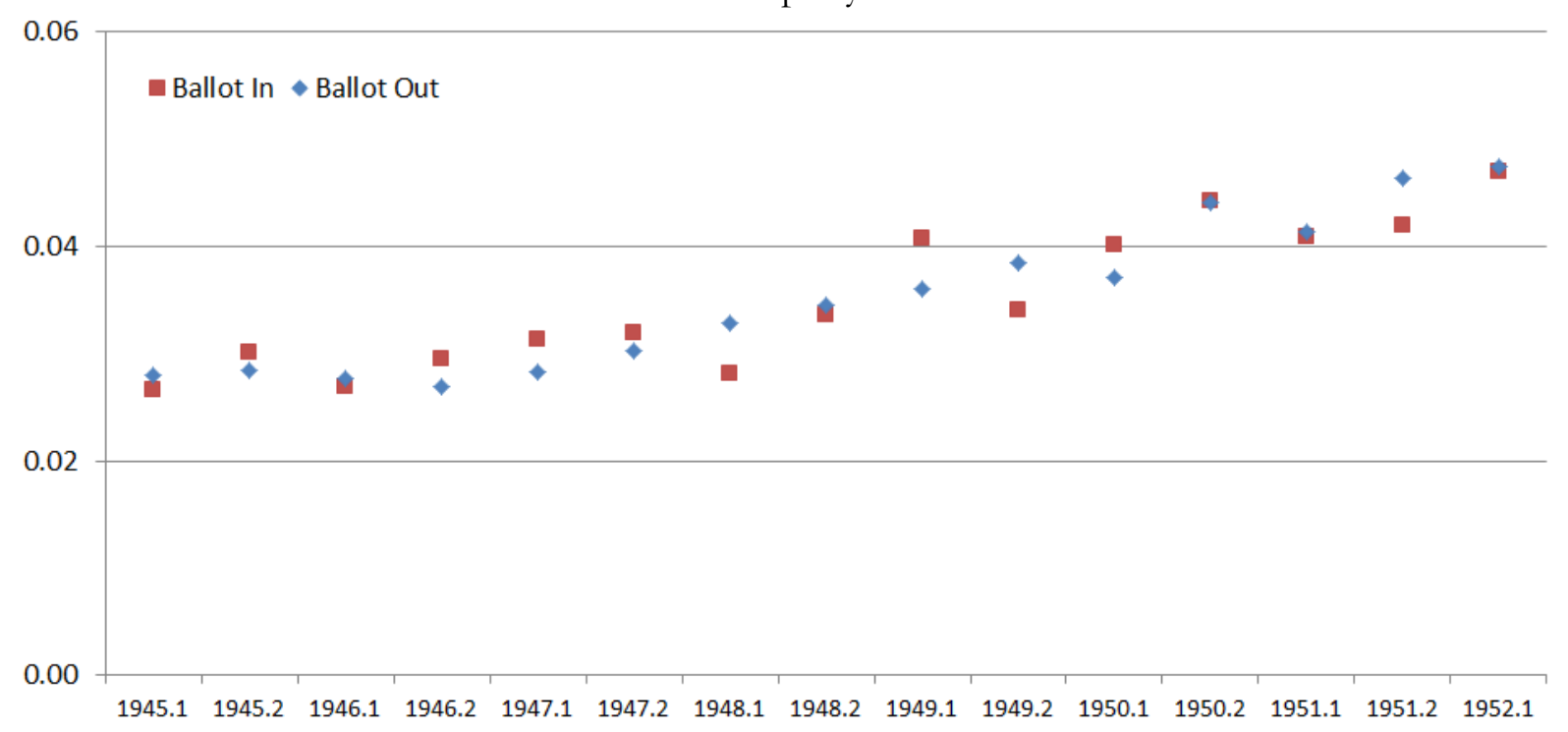

E. Drunk driving crimes

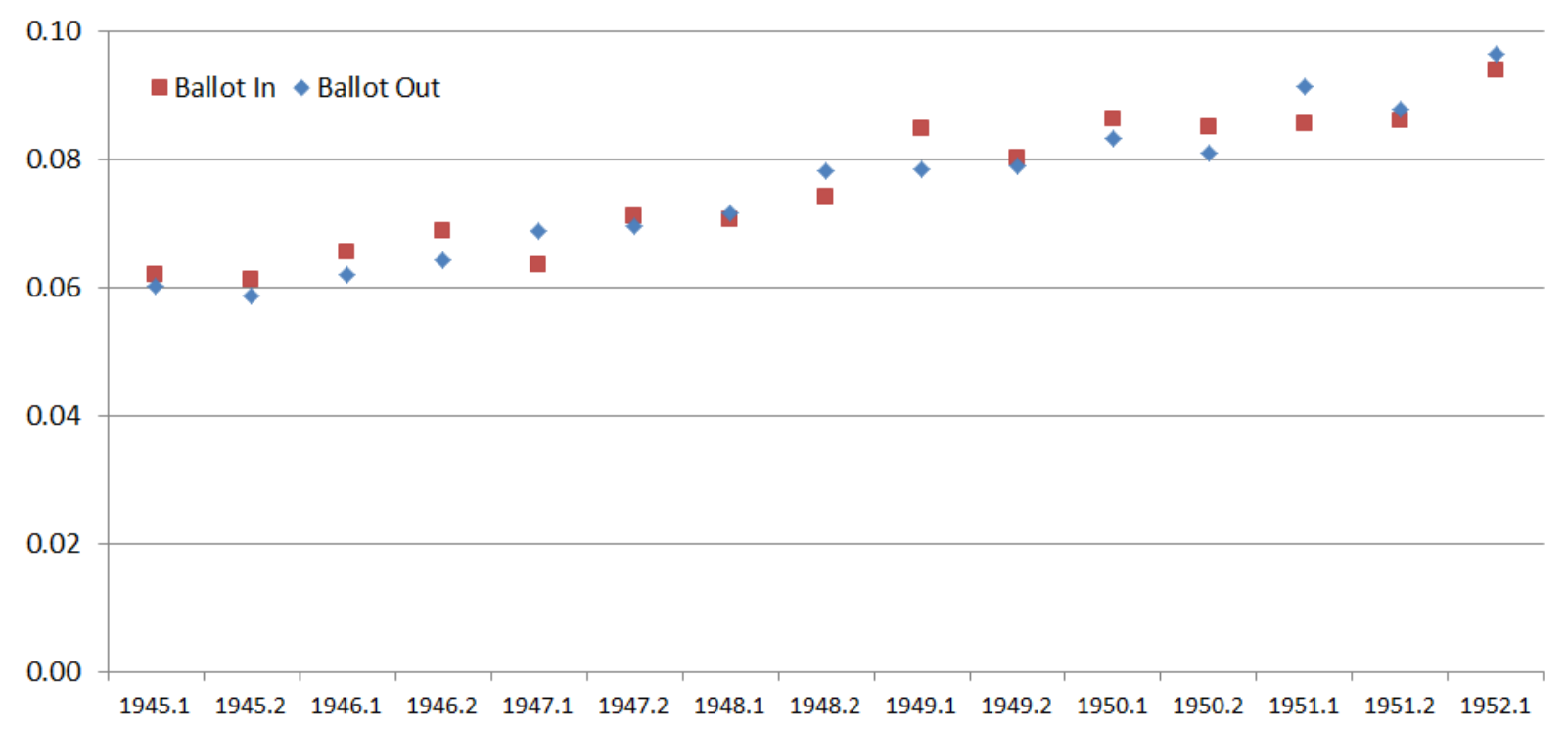


F. Crimes resulting in imprisonment

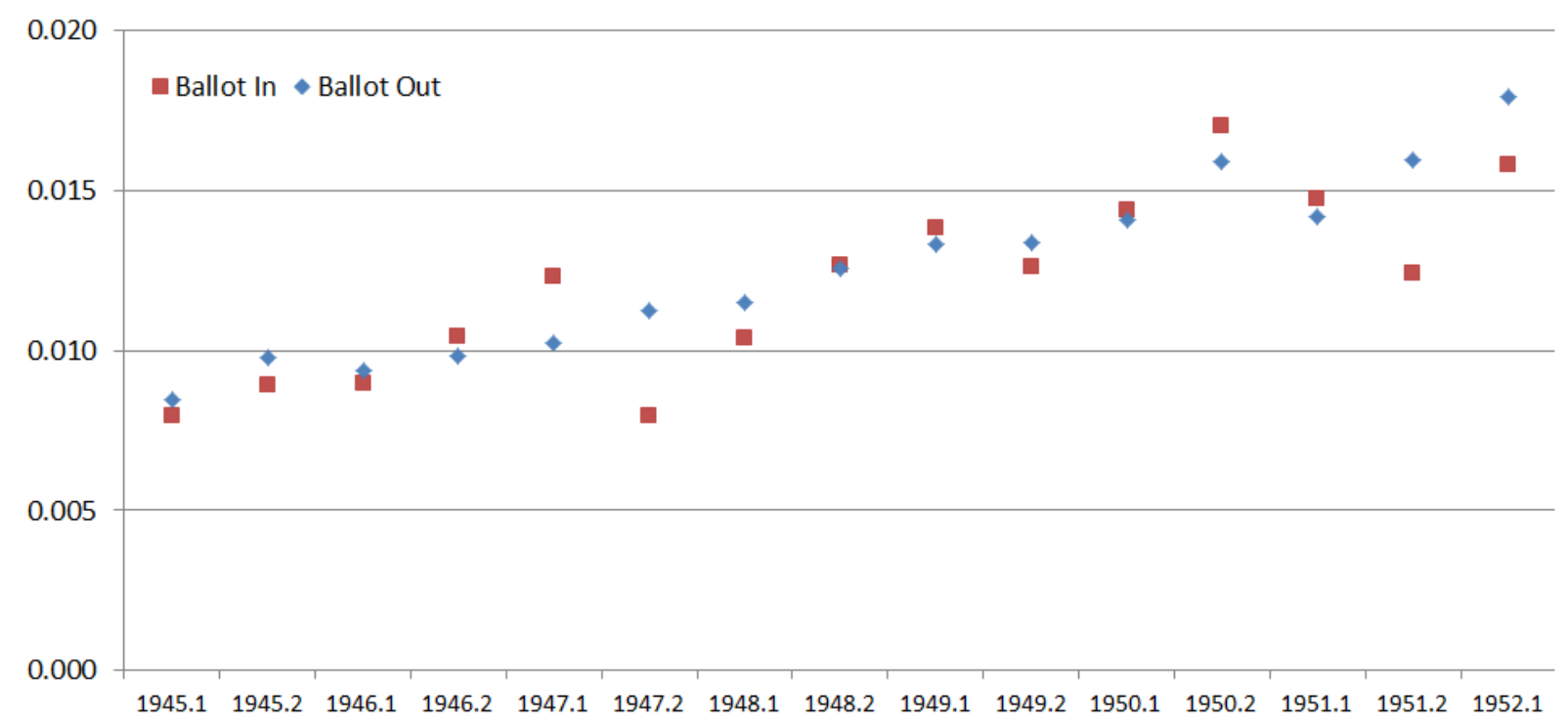

G. Violent crimes resulting in imprisonment

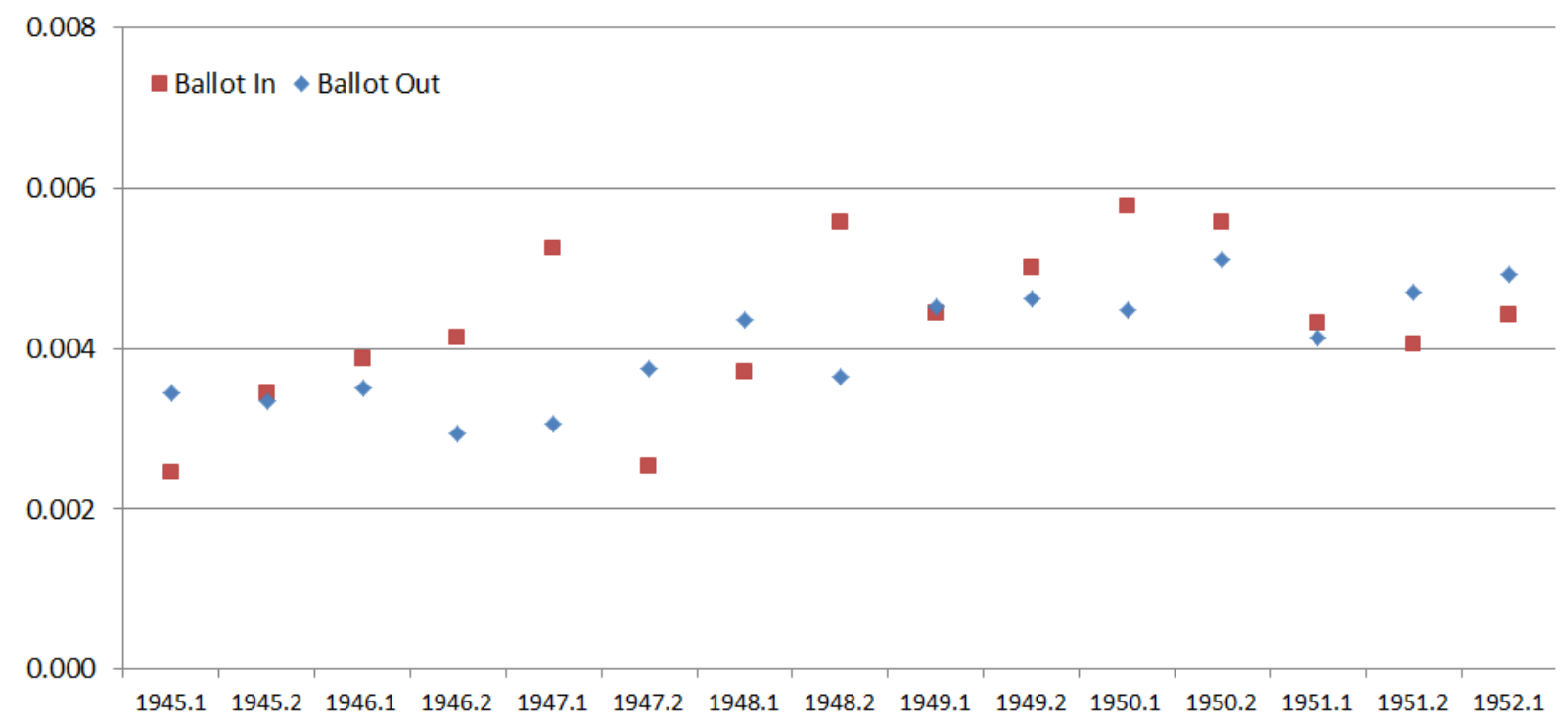

H. Non-violent crimes resulting in imprisonment

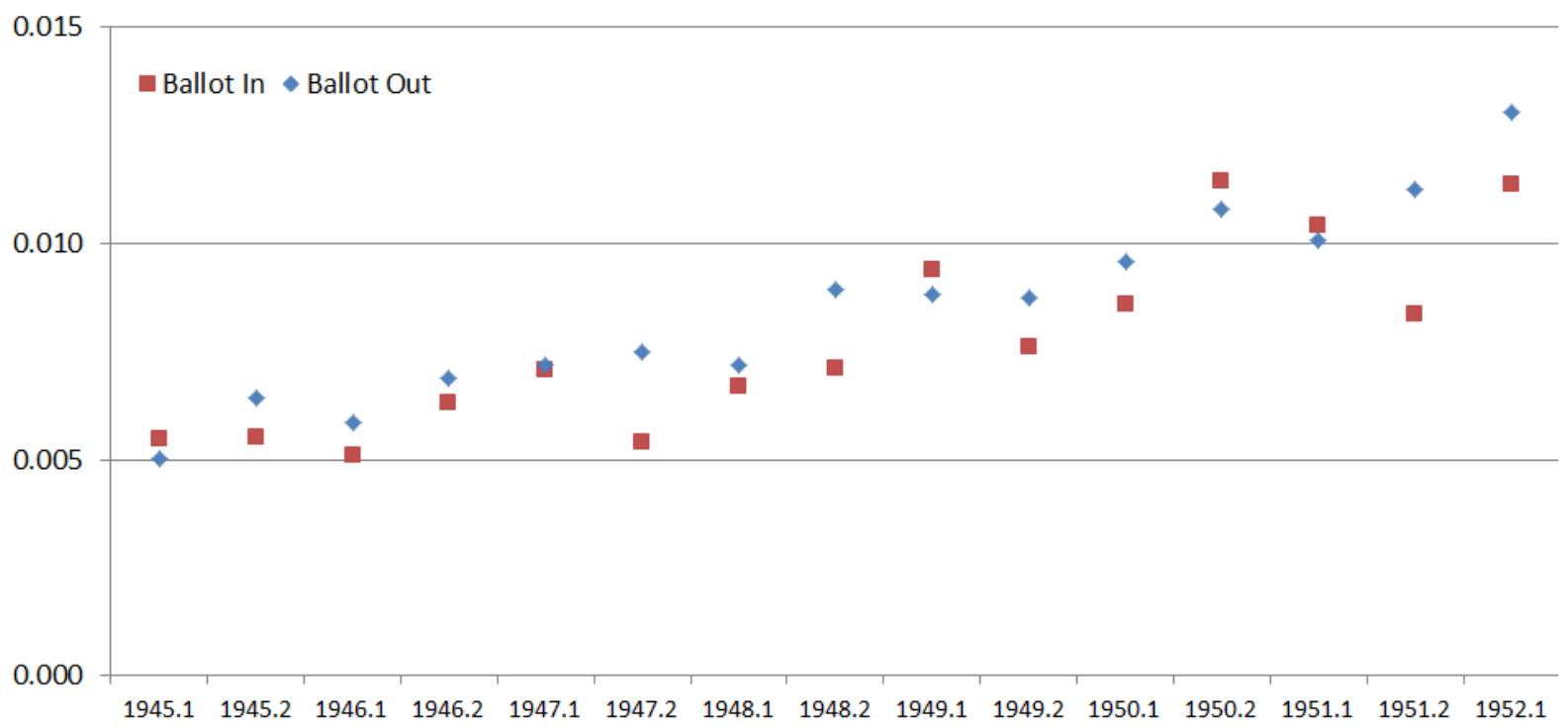


I. Property crimes resulting in imprisonment

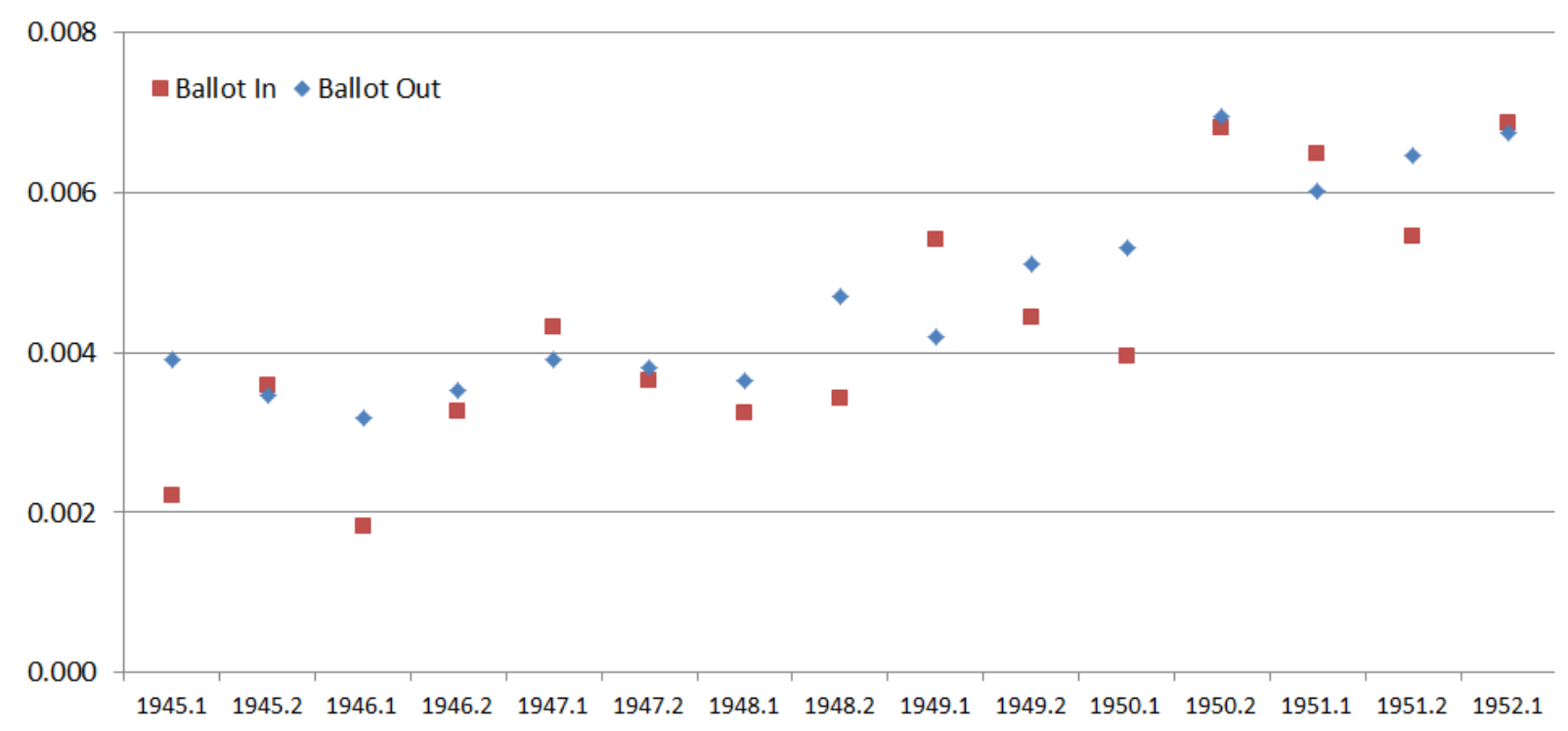


Table A.1 2SLS Estimates for Alternate Categories of Crime: All 15 Birth Cohorts (Models with 2

Endogenous Variables

\begin{tabular}{|c|c|c|c|c|c|c|}
\hline \multirow[b]{2}{*}{ Endogenous variables } & \multirow{2}{*}{$\begin{array}{l}\text { mean of } \\
\text { dependent } \\
\text { variable }\end{array}$} & \multicolumn{5}{|c|}{ Estimated 2SLS effects } \\
\hline & & \multicolumn{2}{|c|}{$\begin{array}{l}\text { point estimates } \\
\text { (robust S.E.s) }\end{array}$} & $\begin{array}{l}\text { point estimate } \\
\text { as } \% \text { of mean }\end{array}$ & \multicolumn{2}{|c|}{$\begin{array}{l}95 \% \text { CI bounds } \\
\text { as } \% \text { of mean }\end{array}$} \\
\hline & \multicolumn{6}{|c|}{ A. Dependent Variable: All crimes } \\
\hline Army service $(r)$ & \multirow{2}{*}{0.264} & -0.005 & $(0.0364)$ & $-2 \%$ & $-29 \%$ & $25 \%$ \\
\hline Army service in Vietnam $(v)$ & & 0.020 & $(0.0946)$ & $8 \%$ & $-63 \%$ & $78 \%$ \\
\hline \multirow{4}{*}{$\begin{array}{l}\text { Army service }(r) \\
\text { Army service in Vietnam }(v)\end{array}$} & \multicolumn{6}{|c|}{ B. Dependent Variable: Violent crimes } \\
\hline & \multirow{2}{*}{0.030} & -0.005 & $(0.0074)$ & $-17 \%$ & $-66 \%$ & $31 \%$ \\
\hline & & 0.015 & $(0.0195)$ & $50 \%$ & $-77 \%$ & $177 \%$ \\
\hline & \multicolumn{6}{|c|}{ C. Dependent Variable: Non-violent crimes } \\
\hline \multirow{2}{*}{$\begin{array}{l}\text { Army service }(r) \\
\text { Army service in Vietnam }(v)\end{array}$} & \multirow{2}{*}{0.234} & 0.000 & $(0.0340)$ & $0 \%$ & $-29 \%$ & $28 \%$ \\
\hline & & 0.005 & $(0.0880)$ & $2 \%$ & $-72 \%$ & $76 \%$ \\
\hline \multirow{3}{*}{$\begin{array}{l}\text { Army service }(r) \\
\text { Army service in Vietnam }(v)\end{array}$} & \multicolumn{6}{|c|}{ D. Dependent Variable: Property crimes } \\
\hline & \multirow{2}{*}{0.035} & -0.007 & $(0.0100)$ & $-19 \%$ & $-74 \%$ & $37 \%$ \\
\hline & & 0.021 & $(0.0253)$ & $60 \%$ & $-80 \%$ & $201 \%$ \\
\hline \multirow{3}{*}{$\begin{array}{l}\text { Army service }(r) \\
\text { Army service in Vietnam }(v)\end{array}$} & \multirow{3}{*}{0.076} & \multicolumn{3}{|c|}{$\underline{\text { E. Drink Driving Crimes }}$} & & \\
\hline & & -0.003 & $(0.0114)$ & $-4 \%$ & $-34 \%$ & $25 \%$ \\
\hline & & 0.021 & $(0.0307)$ & $27 \%$ & $-52 \%$ & $106 \%$ \\
\hline \multirow{4}{*}{$\begin{array}{l}\text { Army service }(r) \\
\text { Army service in Vietnam }(v)\end{array}$} & \multirow{3}{*}{0.012} & \multicolumn{4}{|c|}{$\underline{\text { F. Crimes resulting in Imprisonment }}$} & \\
\hline & & -0.004 & $(0.0062)$ & $-31 \%$ & $-129 \%$ & $67 \%$ \\
\hline & & 0.006 & $(0.0162)$ & $46 \%$ & $-209 \%$ & $301 \%$ \\
\hline & \multicolumn{6}{|c|}{ G. Violent crimes resulting in Imprisonment } \\
\hline \multirow{2}{*}{$\begin{array}{l}\text { Army service }(r) \\
\text { Army service in Vietnam }(v)\end{array}$} & \multirow{2}{*}{0.004} & 0.000 & $(0.0028)$ & $8 \%$ & $-125 \%$ & $141 \%$ \\
\hline & & 0.003 & $(0.0073)$ & $66 \%$ & $-282 \%$ & $415 \%$ \\
\hline \multirow{4}{*}{$\begin{array}{l}\text { Army service }(r) \\
\text { Army service in Vietnam }(v)\end{array}$} & \multicolumn{6}{|c|}{$\underline{\text { H. Non-violent crimes resulting in Imprisonment }}$} \\
\hline & \multirow{2}{*}{0.008} & -0.004 & $(0.0051)$ & $-50 \%$ & $-169 \%$ & $69 \%$ \\
\hline & & 0.003 & $(0.0131)$ & $36 \%$ & $-270 \%$ & $342 \%$ \\
\hline & \multicolumn{6}{|c|}{ I. Property crimes resulting in Imprisonment } \\
\hline Army service $(r)$ & \multirow{2}{*}{0.005} & -0.002 & $(0.0039)$ & $-45 \%$ & $-209 \%$ & $118 \%$ \\
\hline Army service in Vietnam $(v)$ & & 0.000 & $(0.0098)$ & $7 \%$ & $-403 \%$ & $419 \%$ \\
\hline
\end{tabular}

Notes: This table shows 2SLS estimates of the independent effects of army service and the additional effects of deployment to Vietnam (as per equation (3)) on subsequent crime 
perpetration. Each of the nine panels contains results for a particular category of criminal offenses. Cases with one or more guilty verdict are included. The sample includes men from all 15 conscription-eligible birth cohorts (those born between January 1945 and June 1952). A GLS group-means approach is utilised, where the groups are exact dates of birth (DOBs) and the weights are the number of men with each DOB living in NSW, VIC or QLD. In each model, N $=2,738$ DOBs, representing 621,283 men. Each model includes birth cohort fixed effects. Robust standard errors are in parentheses. ${ }^{*} p<0.05,{ }^{* *} p<0.01,{ }^{* * *} p<0.001$ 